\title{
Classification of tropospheric ozone profiles over Johannesburg based on mozaic aircraft data
}

\author{
R. D. Diab ${ }^{1}$, A. Raghunandan ${ }^{1}$, A. M. Thompson ${ }^{2}$, and V. Thouret $^{3}$ \\ ${ }^{1}$ University of Natal, Durban, South Africa \\ ${ }^{2}$ NASA/GFSC, Greenbelt, Maryland, USA \\ ${ }^{3}$ CNRS, Toulouse, France
}

Received: 5 December 2002 - Published in Atmos. Chem. Phys. Discuss.: 12 February 2003

Revised: 26 May 2003 - Accepted: 27 May 2003 - Published: 12 June 2003

\begin{abstract}
Each ozone profile is a unique response to the photochemical and dynamic processes operating in the troposphere and hence is critical to our understanding of processes and their relative contributions to the tropospheric ozone budget. Traditionally, mean profiles, together with some measure of variability, averaged by season or year at a particular location have been presented as a climatology. However, the mean profile is difficult to interpret because of the counteracting influences present in the micro-structure. On the other hand, case study analysis, whilst revealing, only applies to isolated conditions. In a search for pattern and order within ozone profiles, a classification based on a cluster analysis technique has been applied in this study. Ozone profiles are grouped according to the magnitude and altitude of ozone concentration. This technique has been tested with 56 ozone profiles at Johannesburg, South Africa, recorded by aircraft as part of the MOZAIC (Measurement of Ozone and Water Vapor aboard Airbus In-service Aircraft) program. Six distinct groups of ozone profiles have been identified and their characteristics described. The widely recognized spring maximum in tropospheric ozone is identified through the classification, but a new summertime mid-tropospheric enhancement due to the penetration of tropical air masses from continental regions in central Africa has been identified. Back trajectory modeling is used to provide evidence of the different origins of ozone enhancements in each of the classes. Continental areas over central Africa are shown to be responsible for the low to mid-tropospheric enhancement in spring and the mid-tropospheric peak in summer, whereas the winter low-tropospheric enhancement is attributed to local sources. The dominance of westerly winds through the troposphere associated with the passage of a mid-latitude cyclone gives rise to reduced ozone values.
\end{abstract}

Correspondence to: R. D. Diab

(diab@nu.ac.za)

\section{Introduction}

The vertical distribution of ozone is critical to our understanding of both photochemical and dynamic processes that are operating in the atmosphere and contributing to the tropospheric ozone budget. Ozone in the moist boundary layer has a relatively short lifetime of the order of 2-5 days (Fishman et al., 1991), whereas ozone in the free troposphere may last for 2-3 months due to the drier atmosphere and the absence of removal mechanisms such as surface deposition (Liu et al., 1987).

At any particular location there is a large amount of dayto-day variability in the vertical structure of ozone. Not only do the altitudes and magnitudes of maxima and minima change but the vertical structure appears very irregular, sometimes exhibiting marked stratification, with a single or multiple peaks, and at other times exhibiting a uniform profile and absence of structure, indicative of a well-mixed atmosphere.

Each ozone profile is a unique response to photochemical and dynamic processes operating. Hence a study of the profile in terms of its structure, particularly the magnitude and altitudes of maxima and minima, depth of clearly defined layers and the vertical gradient of ozone should reveal insights into these processes. Traditionally, mean profiles averaged by season or year, together with some measure of variability about these means, have been analyzed. Examples of studies that have focused on constructing an ozone climatology for particular locations, include Kirchhoff et al. (1991), Diab et al. (1996), Fortuin and Kelder (1998), Thouret et al. (1998a), Logan (1999) and Thompson et al. (2003). However, computation of the mean tends to obscure the profile micro-structure because of the many counteracting influences present in the data.

On the other hand, case study analysis has been widely used to gain an understanding of processes operating. Examples in which the focus has been on dynamic processes, 
particularly stratospheric-tropospheric exchange (STE) include, Merrill et al. (1996), Cooper et al. (1998), Folkins et al. (1999), Randriambelo et al. (1999), Zachariasse et al. (2000), Scott and Cammas (2002) and Kim et al. (2002). Others, in which strong photochemical forcing was present, include Fujiwara et al. (1999) and Longo et al. (1999). The drawback of case study analysis is that, whilst an understanding of process is gained, there is little contribution to our knowledge of the frequency of occurrence of such events or of their relative importance in the overall ozone budget.

In this paper an alternative approach to the analysis of ozone profiles is adopted. Specifically, a search for pattern and order in the ozone profiles is conducted, in which the objective is to develop a classification of ozone profiles, which can then inform our understanding of the processes that are operating and contributing to the vertical ozone structure.

There have been attempts by other authors to group ozone profiles in terms of certain criteria, however, none has applied an objective multivariate technique as has been done in this study. For example, Newell et al. (1999), characterized four layer types in terms of combinations of ozone and water vapour characteristics, defined as either enhanced $(+)$ or reduced $(-)$. They assigned sources to each and were able to calculate the percentage occurrence of each layer type based on data from the MOZAIC (Measurement of OZone and Water Vapor by Airbus In-service AirCraft) and PEM (Pacific Exploratory Mission) programs. The layer types are defined as follows, with the percentage occurrence indicated in brackets after each type: $\mathrm{O}_{3}+/ \mathrm{H}_{2} 0+$ indicative of continental pollution (11-15\%); $\mathrm{O}_{3}+/ \mathrm{H}_{2} \mathrm{O}-$ characterized by stratospheric air (50-54\%); $\mathrm{O}_{3}-/ \mathrm{H}_{2} 0+$ due to convection from the boundary layer (15-19\%); and $\mathrm{O}_{3}-/ \mathrm{H}_{2} \mathrm{O}-$ indicative of subsiding air originally raised in deep convection over oceans (17-18\%).

\section{Data and methodology}

The classification scheme in this study is developed using ozone profile data from Johannesburg, South Africa $\left(26^{\circ} \mathrm{S}\right.$; $28^{\circ} \mathrm{E}$ ) for the period 1995 to 2000 . The data were derived from the MOZAIC data base, which is designed to collect experimental data on ozone and water vapor in order to improve our understanding of physical and chemical processes in the upper troposphere and lower stratosphere and to validate chemistry and transport models (Marenco et al., 1998). Ozone and water vapor sensors were installed on board five long-range commercial aircraft (Airbus A340's) of four participating airlines. For further details, see the continuously updated web site: http://www.aero.obs-mip.fr/mozaic/

The ozone analyzer is a dual beam UV absorption instrument (Thermo-Electron Model 49-103), which has a detection limit of $2 \mathrm{ppbv}$ and a precision of 2 ppbv. Uncertainties in the measurements are estimated to be $+/-(2 \mathrm{ppbv}+2 \%)$, although actual performance is better (Thouret et al., 1998b).
The response time of the instrument is $4 \mathrm{~s}$ which translates into a vertical resolution of $30 \mathrm{~m}$. Full details of the calibration procedures and mounting in the aircraft are also given in Thouret et al. (1998b).

During the ascent and descent of the aircraft above cities, vertical profiles are recorded. Since the aircraft ascends to or descends from a cruise altitude predefined by international air traffic regulations, the profile data extend to a maximum of $12 \mathrm{~km}$. It is important to note that the aircraft does not ascend/descend vertically above a location but that it follows a well defined flight path which can vary according to wind direction and may extend some $500 \mathrm{~km}$ in the horizontal from the destination. For the purposes of this study this variation has been ignored. Many comparisons have been drawn between commercial or research aircraft and sounding or lidar measurements (such as during PEM-Tropics B). The results are always very good, at least in the troposphere (see for example, Thouret et al., 1998b).

A large number of ozone profiles were assembled for analysis. Of the 516 profiles that were available for Johannesburg over the period 1995-2000, a total of 56 profiles, which had no missing data between the surface and $12 \mathrm{~km}$, were finally selected for the development of the classification scheme. It was deemed preferable to use a small set of profiles in which no interpolation of data had been undertaken rather than a larger set in which data had been interpolated based on the mean.

A cluster analysis program called TWINSPAN (Two-Way Indicator Species Analysis) (Hill, 1979), that is often used in ecological applications to classify plant communities on the basis of species composition, was used. In vegetation studies, the samples are differentiated on the basis of species composition and abundance. In our study, each ozone profile was considered as a sample, and the ozone concentrations at uniform $150 \mathrm{~m}$ intervals of altitude were analogous to species abundance. TWINSPAN makes no assumptions about normality of data and it operates in a divisive manner such that all of the samples are dichotomously divided into groups on the basis of their similarity in species composition. Divisions higher up in the hierarchy are thus more meaningful than those lower down. The idea was to group ozone profiles according to the magnitude and altitude of ozone concentration in a profile. Although a wide variety of cluster analysis techniques are available, TWINSPAN was deemed appropriate as the classification divisions are based on indicator species, defined as those that occur in more than $80 \%$ of the samples of one group and less than $20 \%$ of the other group (Hill, 1979). Analogous to indicator species are the presence of ozone peaks at certain altitudes in this application. It is thus expected that similarities in altitudes and magnitudes of ozone peaks would group profiles together. TWINSPAN is a divisive rather than an agglomerative clustering method and as such the $n$ samples (profiles) are divided successively into a hierarchy of smaller and smaller clusters until finally each cluster contains only one sample or a user-specified small 


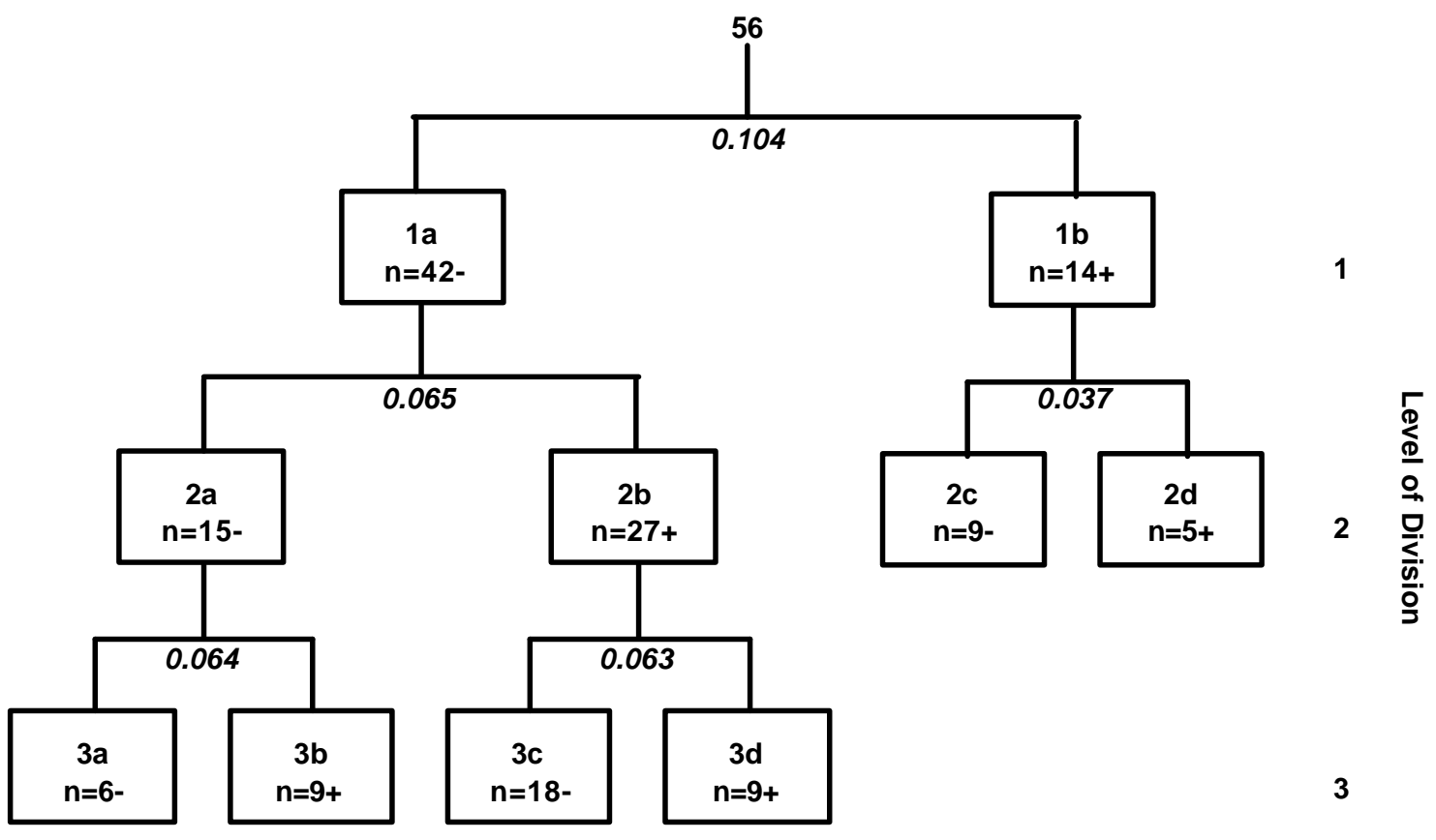

Fig. 1. Dendrogram showing the hierarchical classification of ozone profiles derived from the TWINSPAN cluster analysis for the first three levels of division. The number of profiles is indicated by $n$, with positive and negative signs being used to distinguish the dichotomous groups. Eigenvalues are given in italics. The categories are labeled as $1 \mathrm{a}, 1 \mathrm{~b} .$. up to $3 \mathrm{~d}$. Only the final categories are named as follows: $3 \mathrm{a}$ $=$ single mid-tropospheric peak; $3 \mathrm{~b}=$ steady tropospheric increase; $3 \mathrm{c}=$ reduced tropospheric ozone; $3 \mathrm{~d}=$ lower tropospheric enhancement; $2 \mathrm{c}=$ pronounced layering; $2 \mathrm{~d}=$ considerable tropospheric enhancement.

number of samples. Alternatively, division can be terminated after a certain number of levels of division, once again specified by the user.

In our study, the output was analyzed after three levels of division, since further subdivision represented minor, less meaningful divisions. The extent of similarity between groups is provided by the eigenvalue, which ranges between 0 and 1. A low value indicates a high degree of similarity between groups and an eigenvalue closer to 1 indicates a low degree of similarity.

Back trajectory modelling was undertaken using the Hybrid Single-Particle Integrated Trajectory (HYSPLIT) model, which was jointly developed by the National Oceanic and Atmospheric Administration (NOAA) and modified by the Australian Bureau of Meteorology (Draxler, 1998). The meteorological fields used in the HYSPLIT model were four dimensional gridded fields from the National Centre for Environmental Prediction (NCEP). For this study, 5-day back trajectories were initialised at four standard heights $(2.5,5$, 7.5 and $10 \mathrm{~km}$ ), except for minor modifications in the midtroposphere to take account of observed ozone peaks on particular days. Specifically, for categories $2 \mathrm{c}$ and $3 \mathrm{~d}$ the $5 \mathrm{~km}$ height was replaced by 6 and $4 \mathrm{~km}$ respectively, and for category $3 \mathrm{c}$, the $7.5 \mathrm{~km}$ height was replaced by $8 \mathrm{~km}$. All trajectories were initialised at Johannesburg rather than the actual aircraft location. The influence of this difference in location on individual back trajectories is balanced by a consideration of general indications of source regions based on multiple back trajectories in a group rather than results of an individual case study.

\section{Results}

The breakdown of ozone profiles into classes is summarized by means of the dendrogram presented in Fig. 1 . The first level of division was characterized by one group of 42 profiles (Group 1a), which exhibit generally low ozone values $(<40 \mathrm{ppbv}$ ) in the lower troposphere (below $\sim 4 \mathrm{~km}$ ), compared with the second group of 14 profiles (Group 1b) where ozone was above $40 \mathrm{ppbv}$ at the surface and $\sim 70 \mathrm{ppbv}$ in the lower troposphere. Clearly, this first division delineates the spring ozone profiles from those in other seasons, since in the second group, all but two of the profiles were recorded in spring when surface based emissions are known to maximise in this region (Justice et al., 1996; Scholes and Andreae, 2000). There is also a marked distinction between the two groups at higher altitudes in the troposphere. Midtropospheric peaks extend to $100 \mathrm{ppbv}$ in the spring group (Group 1b), yet seldom exceed $70 \mathrm{ppbv}$ in the first group (Group 1a). Similarly, there is an increasing trend in ozone in the upper troposphere near the tropopause in the spring group (Group 1b) and a generally decreasing trend in the former group (Group 1a). 

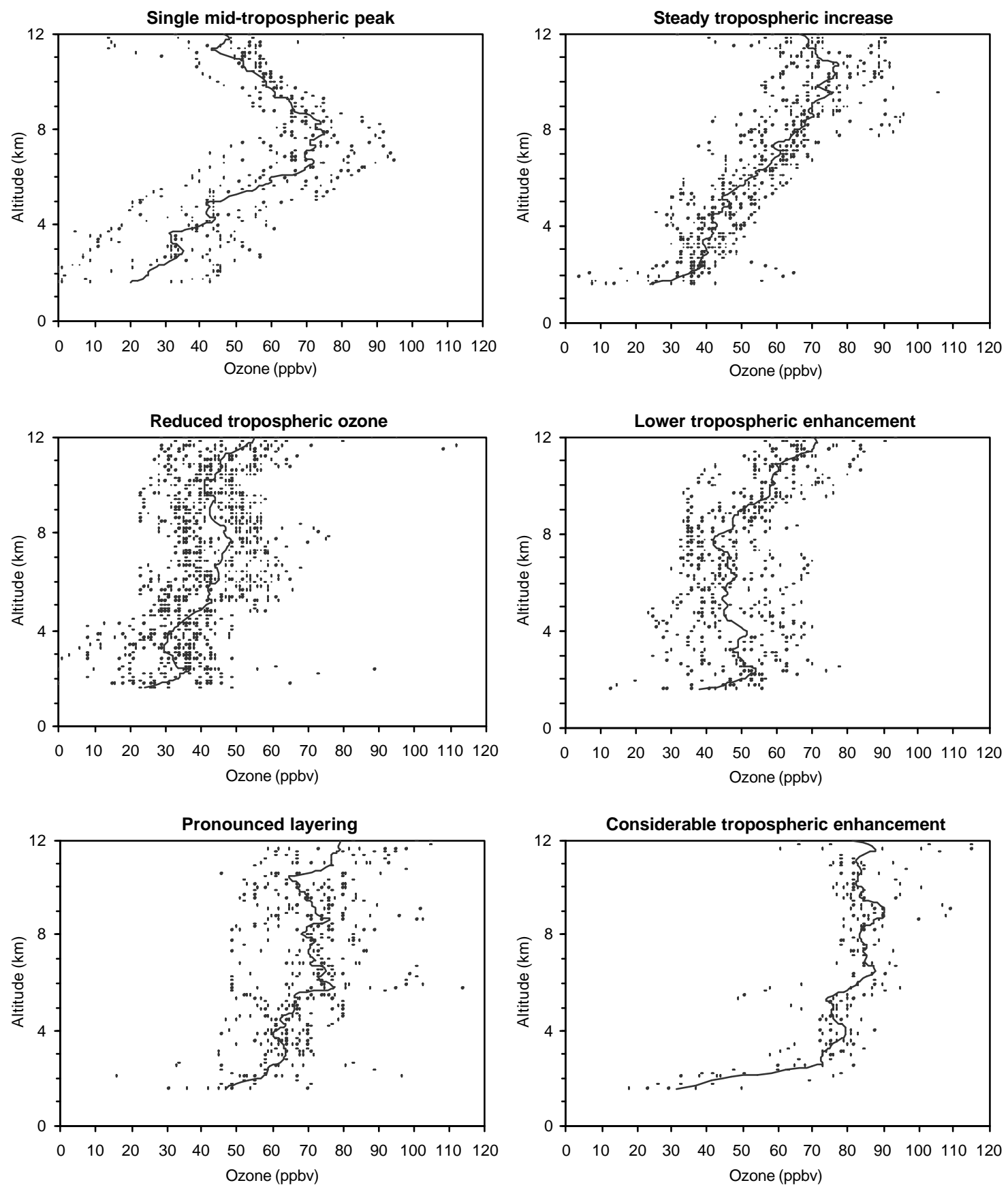

Fig. 2. Mean (solid line) and individual values at $150 \mathrm{~m}$ height intervals (dots) for ozone profiles in 6 categories derived from the cluster analysis.

At the second level of division, the first group (Group 1a) was divided further into one group of 15 (Group 2a) and a second of 27 profiles (Group 2b). The former is associated with a generally increasing trend throughout the lower to mid-troposphere and an enhancement above $8 \mathrm{~km}$, whereas in the second group there is no clear evidence of an enhancement. The spring group of the first level (Group 1b) is now separated into one group of 9 profiles (Group 2c) that is characterized by a distinct layering pattern, with narrow peaks separated by bands of lower ozone. The smaller group of 5 profiles (Group 2d) is characterized by a very steep gradient from the surface to just less than $3 \mathrm{~km}$, where values are $\sim 80 \mathrm{ppbv}$ and then a fairly uniform distribution throughout the troposphere with values consistently between $70-90 \mathrm{ppbv}$ 
and the absence of marked stratification in the profile. Although these latter two groups were subdivided beyond the second level of division, the eigenvalues dropped to fairly low values and so subsequent division was not regarded as meaningful.

The final classification selected for analysis consists of 6 categories, which are defined as follows: single midtropospheric peak (3a); steady tropospheric increase (3b); reduced tropospheric ozone (3c); lower tropospheric enhancement (3d); pronounced layering (2c) and considerable tropospheric enhancement (2d). The figures in brackets after each of the subheadings that follow indicate the number of profiles in each category.

\subsection{Single mid-tropospheric peak (6)}

The mean ozone profile of this category, together with the values for individual profiles at each $150 \mathrm{~m}$ height interval, is illustrated in Fig. 2a. This is a typical Southern Hemisphere summer pattern, in which near-surface ozone values are low, sometimes close to zero, indicative of ozone destruction in the moist boundary layer. Relative humidity values of up to $90 \%$ in individual humidity profiles (not shown) provide evidence of high moisture contents. A single welldefined, broad mid-tropospheric ozone maximum is centred at $6-8 \mathrm{~km}$, where peak values of $80-100 \mathrm{ppbv}$ are recorded. The mean value of this maximum is 70 ppbv. Above this maximum is a layer of relatively lower ozone in which values steadily decrease from the peak to values of $\sim 45 \mathrm{ppbv}$ at $12 \mathrm{~km}$. The reduced ozone here is most likely the result of convective outflow of ozone-poor air lifted from the boundary layer. It also reflects the high position of the tropopause at this time of year and the consequent absence of the steep ozone increase expected in the vicinity of the tropopause. The one exception in which high ozone values are evident around $12 \mathrm{~km}$ (Fig. 2a), belongs to a winter profile, the only one in the group, and is indicative of a lower tropopause position at this time of year and the penetration of relatively higher stratospheric ozone to these altitudes.

Results of 5-day back trajectory modelling for all days within this group are overlaid and depicted in Fig. 3a. Nearsurface transport (back trajectory initialised at an altitude of $2.5 \mathrm{~km}$ ) is from the northern and eastern sectors (red trajectories) and is associated with anticyclonic circulation of moist maritime air. Trajectories generally originated over the Indian Ocean between the north-east and south-east, thus accounting for the high relative humidities recorded on these days and the low near-surface ozone values. Midtropospheric transport between 5 and $7.5 \mathrm{~km}$ (blue and green trajectories) was generally out of the west, although in two of the cases, easterly transport extended upwards from the surface. The most distinguishing feature of this group is the descending movement of air in the upper troposphere (evident in the vertical cross section insert in Fig. 3a for a particular case study) in a spiralling anticyclonic circulation, with tra- jectories generally originating over continental areas to the north rather than from the west. In one case, air originated over the Democratic Republic of the Congo and descended from approximately $12 \mathrm{~km}$ to $8.7 \mathrm{~km}$, most likely being responsible for the long-range transport of ozone-rich air from African countries to the north of Johannesburg. Strong summer convective activity in the lower latitudes would be able to mix surface generated ozone precursors (possibly from biomass burning which is known to exist at this time of year (Hao et al., 1996) to higher altitudes where ozone has a longer lifetime (Liu et al., 1987). Coupled with convective enhancement (Pickering et al., 1990; 1992; 1993) this would account for the relatively high ozone air transported southwards.

\subsection{Steady tropospheric increase (9)}

The absence of a single well-defined peak, but a generally increasing trend in ozone, with individual profiles characterized by the presence of multiple laminae of the order of 5 $15 \mathrm{ppbv}$ in magnitude and at variable altitudes, characterize this group (Fig. 2b). Most of the profiles in this category occur in summer (7), with 2 in spring. An example of a typical individual ozone profile (23 December 1995), which clearly depicts the layered structure is plotted in Fig. 4, together with the corresponding relative humidity profile. Similar laminar structures have been detected by Newell et al. (1999), who noted that they varied in thickness from $0.5-1.3 \mathrm{~km}$ and occurred at altitudes ranging between 5.5 and $6.6 \mathrm{~km}$. They suggested that such features originated from upward motion and subsequent lateral spreading associated with deep convection.

The distinguishing feature of this group in terms of the source region of air masses is that most of the mid- to uppertropospheric $(5-10 \mathrm{~km})$ trajectories originate from the southwest over the Atlantic Ocean. There is evidence of relatively light winds over the subcontinent and stronger westerly winds over the Atlantic Ocean. The origin of near-surface air (red trajectories) is variable. Generally, winds are out of the east but may also be of continental origin, which accounts for the considerable variability indicated in near-surface ozone (Fig. 2b).

\subsection{Reduced tropospheric ozone (18)}

This is the largest group of profiles and consequently does not display the coherence of other groups, evidenced by the relatively large spread of values about the mean (Fig. 2c). Distinguishing features are the generally low ozone levels throughout the troposphere. In the mean profile, values lie below $50 \mathrm{ppbv}$. The mean profile displays a shallow nearsurface enhancement ( $38 \mathrm{ppbv}$ ) up to $3 \mathrm{~km}$, relatively low values ( $\sim 30 \mathrm{ppbv}$ ) between 3 and $5 \mathrm{~km}$ and a second broader mid-tropospheric enhancement between $5-8 \mathrm{~km}$. Generally, the low level ozone values do not exceed $50 \mathrm{ppbv}$, but there 


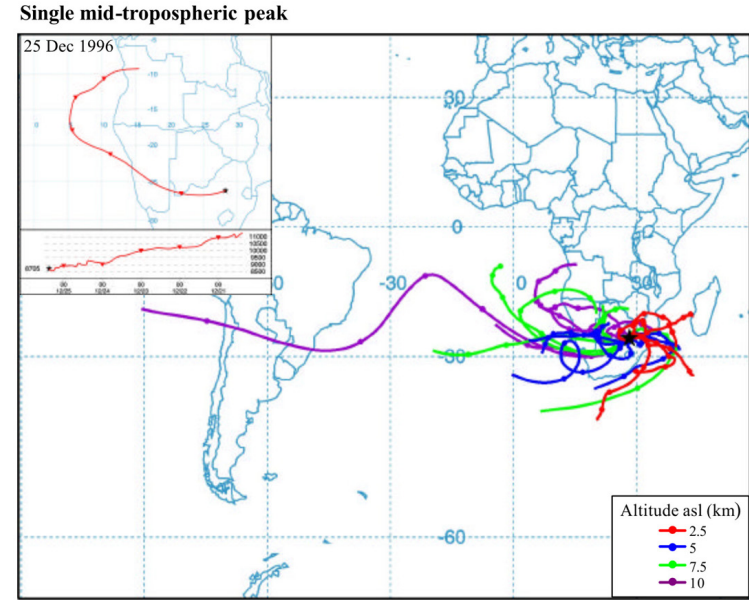

(a)

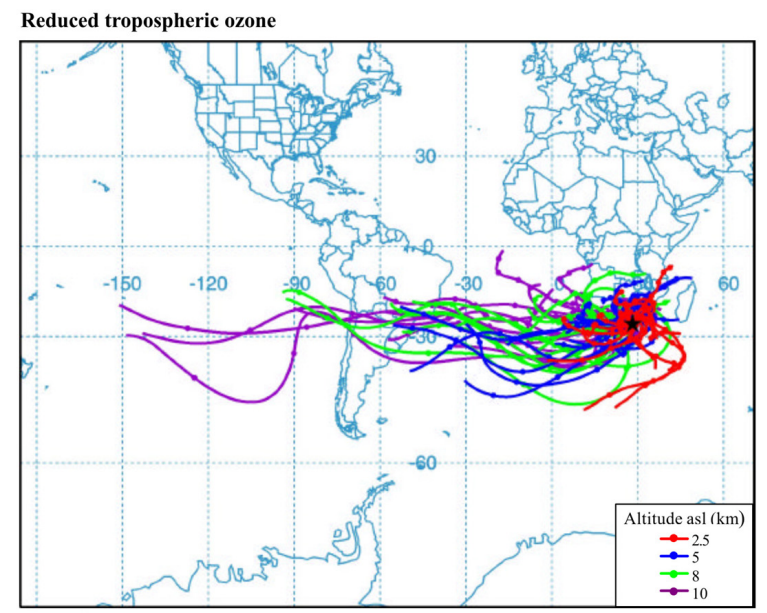

(c)

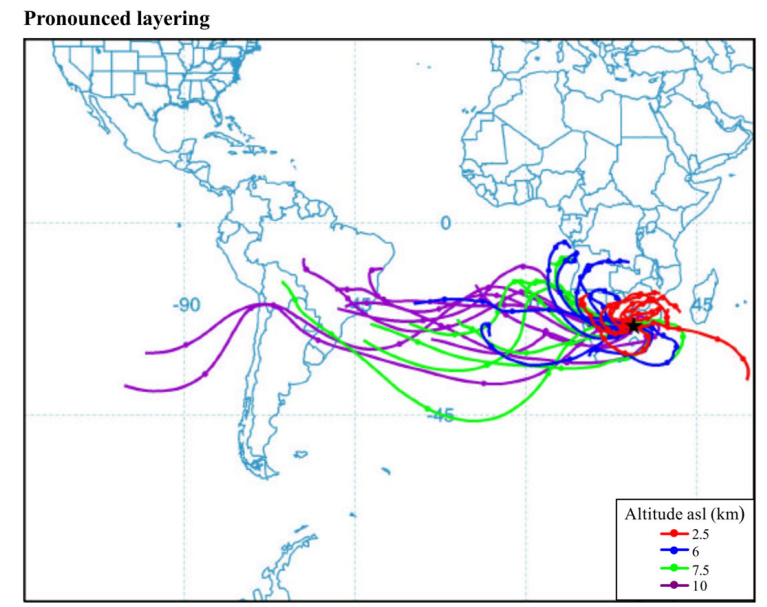

(e)

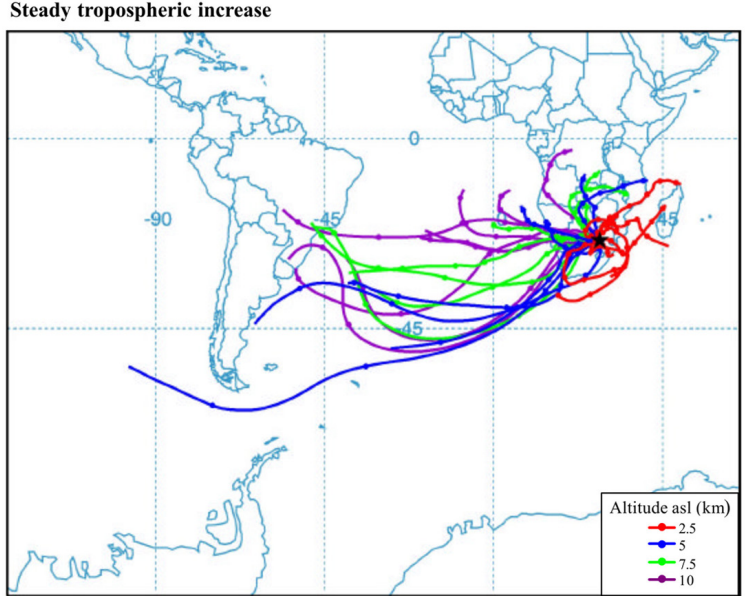

(b)

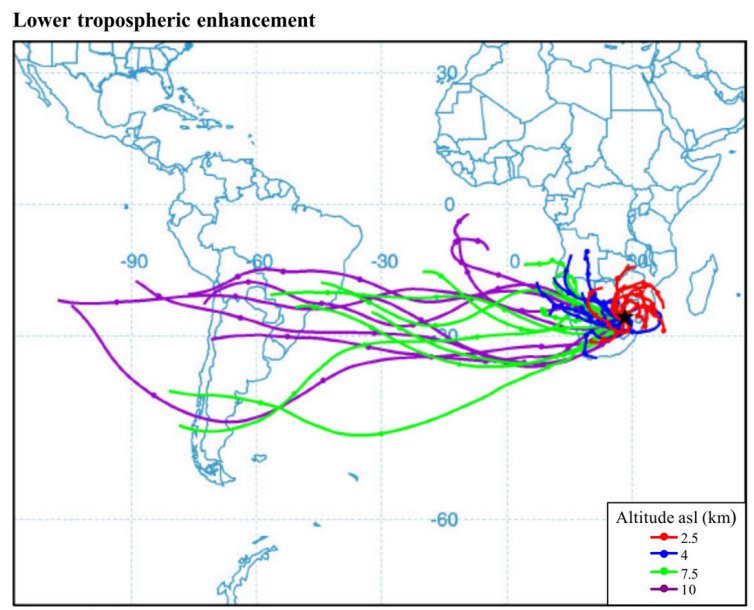

(d)

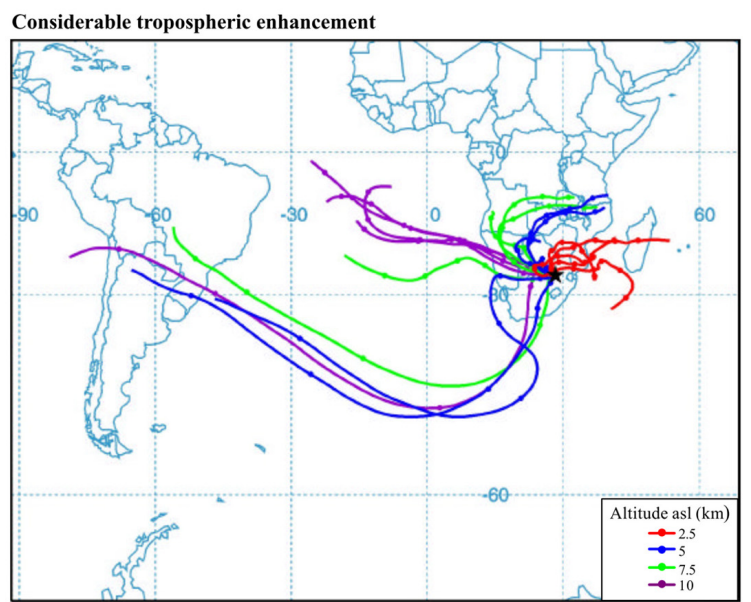

(f)

Fig. 3. Five-day back trajectory HYSPLIT model results for (a) single mid-tropospheric peak category; (b) steady tropospheric increase; (c) reduced tropospheric ozone; (d) lower tropospheric enhancement; (e) pronounced layering; (f) considerable tropospheric enhancement. Trajectories originating at $2.5 \mathrm{~km}$ are red, $5 \mathrm{~km}$ blue, $7.5 \mathrm{~km}$, green and $10 \mathrm{~km}$ purple. The insert in a) shows the results of the $10 \mathrm{~km}$ back trajectory and vertical cross section for 25 December 1996. 


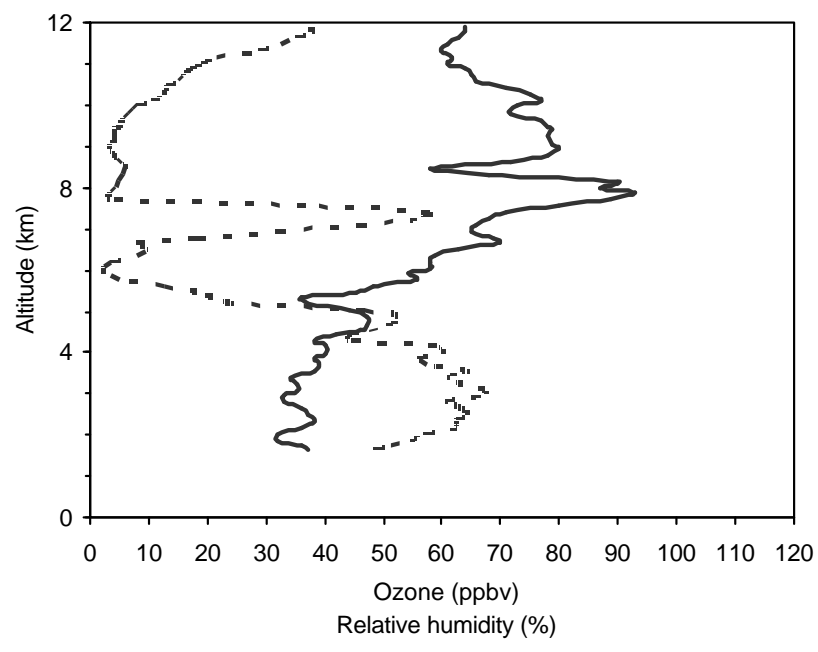

Fig. 4. Vertical distribution of ozone (ppbv) and relative humidity (\%) at Johannesburg for 23 December 1995.

are two cases where this maximum is more pronounced. Another distinguishing feature of this group is the generally increasing ozone trend in the upper troposphere, reflecting the lower winter position of the tropopause and the possible penetration of stratospheric air to lower levels. Most of these profiles (16) occur in either autumn or winter, when the northward displacement of the mean subtropical anticyclones permits the invasion of westerly winds through a deep layer of the atmosphere over southern Africa to a greater extent than at other times of the year.

Back trajectory modelling reveals the dominance of westerly airflow throughout the troposphere (Fig. 3c). The maritime origin of air over the Atlantic Ocean is responsible for the relatively low ozone values in these cases. At times, the low level origin of air masses (red trajectories) is from the south-east rather than the west, representing flow to the rear of the mid-latitude frontal system, but its maritime origin again gives rise to low ozone values. In a few cases, the lowlevel origin of air is over Africa (predominantly Botswana and Zimbabwe), however, the lack of significant biomass burning emissions during the autumn and winter seasons account for the comparatively low ozone levels.

\subsection{Lower tropospheric enhancement (9)}

The distinctive feature of this group is the presence of a lower tropospheric enhancement, where the mean ozone value is above $50 \mathrm{ppbv}$, accompanied by a deep layer in the midtroposphere $(5-8 \mathrm{~km})$ of relatively lower ozone values. Individual profiles show lower tropospheric values in excess of $70 \mathrm{ppbv}$ (Fig. 2d). The peak is generally confined below $5 \mathrm{~km}$, which coincides with the height of the persistent and ubiquitous absolutely stable layer which has been described by Cosijn and Tyson (1996) and which is recognized as be- ing a significant influence on the vertical distribution of trace gases and aerosols over southern Africa (Tyson et al., 1997). Essentially it inhibits vertical mixing and confines boundary layer photochemically-generated ozone to the lower troposphere. Most of the profiles in this group occur in autumn or winter when the absolutely stable layer is most pronounced, but there are 1 or 2 profiles from each of the other seasons.

Back-trajectory modelling confirms the presence of a strong discontinuity in the atmosphere (Fig. 3d). Below $5 \mathrm{~km}$ there is evidence of anticyclonic recirculation and light winds (red trajectories), which are responsible for the build-up of lower tropospheric ozone (Fig. 2d). Above $5 \mathrm{~km}$ air parcels have been advected in strong westerly flow from the Atlantic Ocean, bringing clean maritime air to the mid-troposphere over Johannesburg (blue, green and purple trajectories in Fig. 3d). The increasing ozone between 9 and $12 \mathrm{~km}$ most likely reflects the lower altitude of the winter tropopause and the possible penetration of stratospheric air to lower levels (Fig. 2d).

\subsection{Pronounced layering (9)}

All these profiles display pronounced stratification, with ozone differing by $\sim 50 \mathrm{ppbv}$ within a few hundred metres. Peaks are high, up to $110 \mathrm{ppbv}$, but are narrow and variable in height. There is considerable variation about the mean depicted in Fig. 2e, which obscures the marked layering evident in individual profiles. All, except 2 profiles, occur in spring when tropospheric ozone values are known to be highest (for example Diab et al., 1996; Thompson et al., 1996).

Back trajectory modelling (Fig. 3e) reveals that the origin of air masses throughout the lower and mid-troposphere (up to $5 \mathrm{~km}$ ) is predominantly continental and to the north of Johannesburg (red and blue trajectories). Only in the upper troposphere (back trajectories originating at 7.5 and $10 \mathrm{~km}$ ) is the source region from the west, with air masses characterized by cleaner maritime air (green and purple trajectories).

\subsection{Considerable tropospheric enhancement (5)}

The final group of spring profiles displays a sharp increase in ozone from the surface to $2.5 \mathrm{~km}$, and then elevated ozone values, of the order of $80-100 \mathrm{ppbv}$, throughout the troposphere (Fig. 2f). There is relatively little deviation about these mean values. It is anticipated that these would be the days of highest total tropospheric ozone (TTO) and indeed, TTO, estimated by integrating ozone profiles between the surface and $12 \mathrm{~km}$, ranged between 35.7 and $39.3 \mathrm{DU}$ and included some of the highest values recorded.

Movement of air generally of continental origin in a large anticyclonic gyre over the subcontinent is responsible for the high ozone values recorded. Figure $3 \mathrm{f}$ displays the composite results of back trajectory modelling for this category. Trajectories frequently originate north of $15^{\circ} \mathrm{S}$ over locations which are widely acknowledged as key biomass burning regions at 


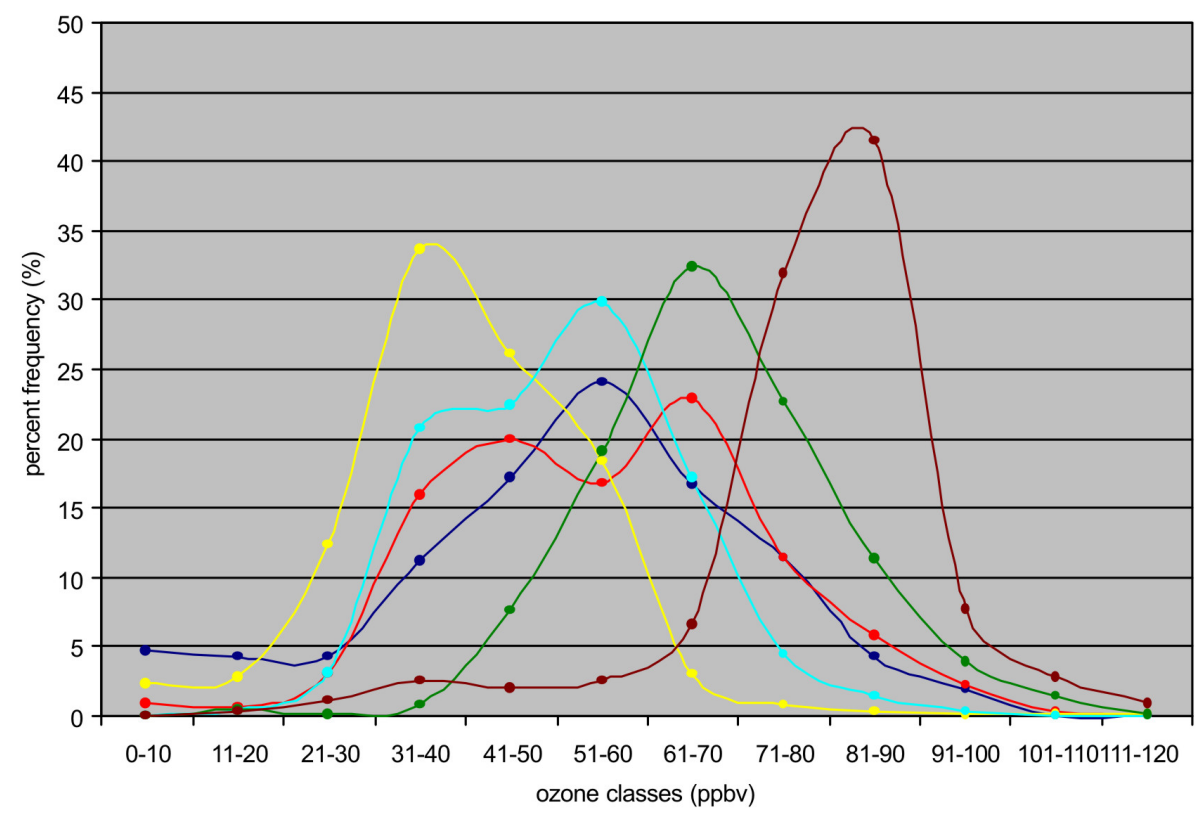

Fig. 5. Frequency distribution of ozone values within each of the 6 defined profile categories. Dark blue = single mid-tropospheric peak; red = steady tropospheric increase; yellow = reduced tropospheric ozone; light blue = lower tropospheric enhancement; green = pronounced layering; brown = considerable tropospheric enhancement.

this time of year. Only at the highest level $(10 \mathrm{~km})$ is there evidence of the dominance of westerly flow (purple trajectories).

\section{Analysis}

The marked differences between groups are highlighted by ozone frequency distributions within each group (Fig. 5). Here ozone values (at $150 \mathrm{~m}$ height intervals) from individual profiles within each group have been binned into ozone classes, defined in intervals of $10 \mathrm{ppbv}$ ranging from 0 to $120 \mathrm{ppbv}$, and expressed as percent frequencies.

Group 1 (single mid-tropospheric peak) is characterized by a broad unimodal distribution, with most of the ozone values lying between 51-60 ppbv. It also has a relatively higher frequency of very low values $(<30 \mathrm{ppbv})$ than other groups, due to near-surface destruction of ozone. Groups 2 (steady tropospheric increase) and 4 (lower tropospheric enhancement) display similar frequency distributions with modal classes of 61-70 ppbv and 51-60 ppbv respectively. The third group (reduced tropospheric ozone) exhibits a frequency shift to lower ozone values (31-40 ppbv) and very few values $(4.4 \%)$ above 60 ppbv. Groups 5 (pronounced layering) and 6 (considerable tropospheric enhancement) exhibit a frequency shift to higher ozone values and have modal classes of 61-70 and 81-90 ppbv respectively, reflecting the springtime ozone enhancement. They are also characterized by low frequencies at the lower end of the scale. In group 6 , less than $9 \%$ of the ozone values lie below $60 \mathrm{ppbv}$.
The classification has clearly emphasized the pronounced seasonality of ozone profiles (Table 1). Although there is some spread among groups it is evident that seasons are dominated by particular patterns and by inference, the processes and transport patterns that shape the individual profiles are seasonally dependent. Spring is characterized by either "pronounced layering" or "considerable tropospheric enhancement", indicative of strong photochemical production from biomass burning and biogenic sources in this season. Summer profiles exhibit a "mid-tropospheric peak" when upper air masses originate from continental areas to the north indicative of southward penetration of the Inter-Tropical Convergence Zone (ITCZ), or a "steady tropospheric increase" when the troposphere is characterized by predominantly westerly flow that originates over the Atlantic Ocean. Autumn profiles fall predominantly into the "reduced tropospheric ozone" group caused by the dominance of westerly flow throughout the troposphere. Winter profiles are spread between "reduced tropospheric ozone" and the category with a "lower tropospheric enhancement". It is widely known that spring is the season when tropospheric ozone maximizes as has been confirmed in this study. However, the equally high, summer mid-tropospheric peak as typified by the first category has not been previously identified over southern Africa. The mid-tropospheric peak and its trajectory origins may correspond to the region of high mid-tropospheric ozone during summer observed by Thompson et al. (2000) over the South Atlantic between $5-20^{\circ} \mathrm{S}$. In an investigation of TTO, these cases would not have emerged as particularly high TTO days 
Table 1. Distribution of cases within each ozone profile group by season

\begin{tabular}{cccccccc}
\hline \multicolumn{9}{c}{ Groups } \\
\hline & $\begin{array}{c}\text { Single } \\
\text { mid-tropospheric } \\
\text { peak }\end{array}$ & $\begin{array}{c}2 \\
\text { Steady } \\
\text { tropospheric } \\
\text { increase }\end{array}$ & $\begin{array}{c}\text { Reduced } \\
\text { tropospheric } \\
\text { ozone }\end{array}$ & $\begin{array}{c}\text { Lower } \\
\text { tropospheric } \\
\text { enhancement }\end{array}$ & $\begin{array}{c}\text { Pronounced } \\
\text { layering }\end{array}$ & $\begin{array}{c}\text { Considerable } \\
\text { tropospheric } \\
\text { enhancement }\end{array}$ & Total \\
Spring & 0 & 2 & 0 & 1 & 7 & 5 & 15 \\
Summer & 5 & 7 & 2 & 2 & 0 & 0 & 16 \\
Autumn & 0 & 0 & 12 & 2 & 1 & 0 & 15 \\
Winter & 1 & 0 & 4 & 4 & 1 & 0 & 10 \\
\hline
\end{tabular}

because of the counteracting influence of the very low nearsurface ozone. Furthermore, summer is dominated by two patterns, viz. groups 1 and 2, and hence a study of mean seasonal profiles would have failed to reveal this particular pattern.

Johannesburg is a key location for an analysis of ozone profiles since its latitude is intermediate between tropical and mid-latitude meteorological regimes. Depending on the latitudinal position of the large scale pressure systems, so Johannesburg is dominated by circulation patterns characteristic of either mid-latitude or tropical latitudes. Thus, summer is dominated by tropical influences as the easterly waves and the ITCZ penetrate further south over the subcontinent, and winter by mid-latitude influences as the westerlies penetrate further north, particularly in the upper troposphere. Similar trends are also present at Irene $\left(25.25^{\circ} \mathrm{S} ; 28.22^{\circ} \mathrm{E}\right)$, which was noted by Thompson et al. (2003) to differ from other ozonesonde stations in the SHADOZ (Southern Hemisphere Additional Ozonesondes) network in that it did not always experience a typical tropical climate.

This conclusion has important implications for the computation of trends based on mean profiles at these intermediate latitudes. The mean comprises a mix of tropical and mid-latitude regimes, which are likely to differ in relative contribution from year to year as a function of dynamic factors, such as the latitudinal position of the jet stream. Similar findings have been noted by Hudson et al. (2003). The meteorological regimes in turn may be characterized by different trends due to different anthropogenic activities in tropical and mid-latitude regions. Hence it is suggested that for stations on the boundaries of zonally defined meteorological regimes that the computation of a mean profile and furthermore, extrapolation of trends based on a mean profile is not statistically justified.

The classification has also revealed that trans-boundary sources make a significant contribution to tropospheric ozone enhancement observed at Johannesburg. Table 2 summarizes the source regions for each category as a function of atmospheric layer. The observed springtime enhancements are linked to transport of air from continental areas to the north of Johannesburg. Likewise, the summertime midtropospheric peak is associated with long-range transport of air from central Africa in an anticyclonic circulation. The only peak that appears to be of local origin is that of the "lower tropospheric enhancement" group, in which local anticyclonic circulation is responsible for the low level build-up of ozone beneath the persistent $5 \mathrm{~km}$ absolutely stable layer. Maritime air masses advected in the westerlies generally give rise to relatively lower ozone values. This is particularly evident in the "reduced tropospheric" ozone category, where westerly winds prevail throughout the troposphere.

\section{Conclusions}

The classification of ozone profiles using a multivariate cluster analysis technique known as TWINSPAN has permitted the identification of 6 categories, each of which possesses distinct attributes. Relating the profiles to the origin of air masses through back trajectory modeling has revealed clearly defined source regions. Continental areas over central Africa and long distance transport are source regions for the mid-tropospheric peak in summer and the low to midtropospheric enhancement in spring, whereas the winter low tropospheric enhancement is attributed to local sources. The dominance of westerly winds through the troposphere gives rise to reduced ozone values. This investigation has emphasized the pronounced seasonality of tropospheric ozone vertical distribution suggesting that there are distinct tropical and mid-latitude influences which give rise to different vertical structures. Drawbacks of focusing on mean profiles when estimating trends are highlighted.

The widely recognized spring maximum in tropospheric ozone has been endorsed in this classification, but a new summertime mid-tropospheric enhancement due to the penetration of tropical air masses from continental regions in central Africa has been identified.

Acknowledgements. RDD and AR acknowledge funding from NRF, Pretoria and the University of Natal Research Fund. AMT acknowledges support from the NASA ACMAP and TOMS projects. The Fulbright Commission enabled RD to undertake an extended 
Table 2. Source regions of air masses associated with each ozone profile category as a function of height

\begin{tabular}{lccccc}
\hline Category & $\begin{array}{c}\text { Near-surface } \\
(2.5 \mathrm{~km})\end{array}$ & $\begin{array}{c}\text { Mid-troposphere } \\
(5 \mathrm{~km})\end{array}$ & $\begin{array}{c}\text { Mid-troposphere } \\
(7.5 \mathrm{~km})\end{array}$ & $\begin{array}{c}\text { Upper troposphere } \\
(10 \mathrm{~km})\end{array}$ & $\begin{array}{c}\text { Dominant } \\
\text { season }\end{array}$ \\
\hline $\begin{array}{c}\text { 1. Mid- } \\
\text { tropospheric } \\
\text { peak }\end{array}$ & East-Indian Ocean & West & West & North-continental Africa & Summer \\
$\begin{array}{c}\text { 2. Steady } \\
\text { tropospheric } \\
\text { increase }\end{array}$ & Variable, generally east & West & West & West & Summer \\
$\begin{array}{c}\text { 3. Reduced } \\
\text { tropospheric }\end{array}$ & West & West & West & West & Autumn \\
$\begin{array}{c}\text { ozone } \\
\text { 4. Lower } \\
\text { tropospheric } \\
\text { enhancement }\end{array}$ & Local, continental & West & West & West & Winter \\
$\begin{array}{c}\text { 5. Pronounced } \\
\text { layering }\end{array}$ & North-continental Africa & North-continentalAfrica & West & West & Spring \\
$\begin{array}{c}\text { 6. Considerable } \\
\text { tropospheric } \\
\text { enhancement }\end{array}$ & North-continental Africa & North-continental Africa & North-continental Africa & West & Spring \\
\hline
\end{tabular}

visit to the United States, which facilitated this collaboration. ESSIC at the University of Maryland is thanked for their hospitality during this period. Funding from a Franco-South African research grant facilitated co-operation between RD and VT. We acknowledge the essential support of airlines participating in the MOZAIC program (Air France, Lufthansa, Austrian Airlines and Sabena).

\section{References}

Cooper, O. R., Moody, J. L., Davenport, J. C., Oltmans, S. J., Johnson, B. J., Chen, X., Shepson, P. B., and Merrill, J. T.: Influence of springtime weather systems on vertical ozone distributions over three North American sites, Journal of Geophysical Research, 103 (D17), 22 001-22 013, 1998.

Cosijn, C. and Tyson, P. D.: Stable discontinuities in the atmosphere over South Africa, South African Journal of Science, 92, 381386, 1996.

Diab, R. D., Thompson, A. M., Zunckel, M., Coetzee, G. J. R., Combrink, J., Bodeker, G. E., Fishman, J., Sokolic, F., McNamara, D. P., Archer, C. B., and Nganga, D.: Vertical ozone distribution over southern Africa and adjacent oceans during SAFARI92, Journal of Geophysical Research, 101 (D19), 23 823$23833,1996$.

Draxler, R. R.: An overview of HYSPLIT-4 modelling system for trajectories, dispersion and deposition, Australian Meteorological Magazine, 47, 295-308, 1998.

Fishman, J., Fakhruzzaman, K., Cros, B., and Nganga, D.: Identification of widespread pollution in the Southern Hemisphere deduced from satellite analyses, Science, 252, 1693-1696, 1991.

Folkins, I., Loewenstein, M., Podolske, J., Oltmans, S. J., and Profitt, M.: A barrier to vertical mixing at $14 \mathrm{~km}$ in the tropics: Evidence from ozonesondes and aircraft observations, Journal of Geophysical Research, 104, 22 095-22 102, 1999.
Fortuin, J. P. F. and Kelder, H.: An ozone climatology based on ozonesonde and satellite measurement, Journal of Geophysical Research, 105 (D24), 31 709-31 734, 1998.

Fujiwara, M., Kita, K., Ogawa, T., Kawakami, S., Sana, T., Komala, N., Saraspriya, S., and Suripto, A.: Tropospheric ozone enhancements during the Indonesian forest fire events in 1994 and in 1997 as revealed by ground-based observations, Geophysical Research Letters, 26 (16), 2417-2420, 1999.

Hill, M. O.: TWINSPAN-A FORTRAN Program for Arranging Multivariate Data in an Ordered Two-Way Table by Classification of the Individuals and Attributes, Cornell University, Ithaca, New York, 1979.

Hudson, R. D., Frolov, A. D., Andrade, M. F., and Follette, M. B.: The total ozone field separated into meteorological regimes. 1 Defining the Regimes, Journal of Atmospheric Science, in press, 2003.

Justice, C. O., Kendall, J. D., Dowty, P. R., and Scholes, R. J.: Satellite remote sensing of fires during the SAFARI campaign using NOAA advanced very high resolution radiometer data, Journal of Geophysical Research, 101 (D19), 23 851-23 863, 1996.

Kim, Y. K., Lee, H. W., Park, J. K., and Moon, Y. S.: The stratosphere-troposphere exchange of ozone and aerosols over Korea, Atmospheric Environment, 36, 449-463, 2002.

Kirchhoff, V. W. J. H., Barnes, R. A., and Torres, A. L.: Ozone climatology at Natal, Brazil, from in situ ozonesonde data, Journal of Geophysical Research, 96 (D6), 10 899-10 909, 1991.

Liu, S. C., Trainer, M., Fehsenfeld, F. C., Parrish, D. D., Williams, E. J., Fahey, D. W., Hubler, G., and Murphy, P. C.: Ozone production in the rural troposphere and implications for regional and global ozone distributions, Journal of Geophysical Research, 92, 10 463-10 482, 1987.

Logan, J. A.: An analysis of ozonesonde data for the troposphere: Recommendations for testing $3 \mathrm{D}$ models and development of gridded climatology for tropospheric ozone, Journal of Geophysical Research, 104 (D13), 16 115-16 149, 1999. 
Longo, K. M., Thompson, A. M., Kirchoff, V. W. J. H., Remer, L. A., de Freitas, S. R., Silva Dias, M. A. F., Artaxo, P., Hart, W., Spinhirne, J. D., and Yamasoe, M. A.: Correlation between smoke and tropospheric ozone concentration in Cuiaba during Smoke, Clouds, and Radiation-Brazil (SCAR-B), Journal of Geophysical Research, 104 (D10), 12 113-12 129, 1999.

Marenco, A., Thouret, V., Nédélec, P., Smit, H., Helten, M., Kley, D., Karcher, F., Simon, P., Law, K., Pyle, J., Poschmann, G., Von Wrede, R., Hume, C., and Cook, T.: Measurement of ozone and water vapor by Airbus in-service aircraft: The MOZAIC airborne program, an overview, Journal of Geophysical Research, 103 (D19), 25 631-25 642, 1998.

Merrill, J. T., Moody, J. L., Oltmans, S. J., and Levy II, H.: Meteorological analysis of tropospheric ozone profiles at Bermuda, Journal of Geophysical Research, 101(D22) 29201-29211, 1996.

Newell, R. E., Thouret, V., Cho, J. Y. N., Stoller, P., Marenco, A., and Smit, H. G.: Ubiquity of quasi-horizontal layers in the troposphere, Nature, 398, 316-319, 1999.

Pickering, K. E., Thompson, A. M., Dickerson, R. R., Luke, W. T., McNamara, D. P., Greenberg, J. P., and Zimmerman, P. R.: Model calculations of tropospheric ozone production potential following observed convective events, Journal of Geophysical Research, 95 (D9), 14 049-14 062, 1990.

Pickering, K. E., Thompson, A. M., Scala, J. R., Tao, W. K., and Simpson, J.: Ozone production potential following convective redistribution of biomass burning emissions, Journal of Atmospheric Chemistry, 14, 297-313, 1992.

Pickering, K., Thompson, A. M., Tao, W. K., and Kucsera, T.: Upper tropospheric ozone production following mesoscale convection during STEP/EMEX, Journal of Geophysical Research, 98 (D5), 8737-8749, 1993

Ramdriambelo, T., Baray, J. L., Baldy, S., Bremaud, P., and Cautenet, S.: A case study of extreme tropospheric ozone contamination in the tropics using in-situ, satellite and meteorological data, Geophysical Research Letters, 26 (9), 1287-1290, 1999.

Scholes, M. and Andreae, M. O.: Biogenic and pyrogenic emissions from Africa and their impact on the global atmosphere, Ambio, 29 (1), 23-29, 2000.
Scott, R. and Cammas, J.-P.: Wave breaking and mixing at the subtropical tropopause, Journal of Atmospheric Sciences, 59 (15), 2347-2361, 2002

Thouret, V., Marenco, A., Nédélec, P., and Grouhel, C.: Ozone climatologies at $9-12 \mathrm{~km}$ altitude as seen by the MOZAIC airborne program between September 1994 and August 1996, Journal of Geophysical Research, 103 (D19), 25 653-25 679, 1998a.

Thouret, V., Marenco, A., Logan, J. A., Nédélec, P., and Grouhel, C.: Comparison of ozone measurements from MOZAIC airborne program and the ozone sounding network at eight locations, Journal of Geophysical Research, 103 (D19), 25 695-25 720, 1998 b.

Thompson, A. M., Diab, R. D., Bodeker, G. E., Zunckel, M., Coetzee, G. J. R., Archer, C. B., McNamara, D. P., Pickering, K. E., Combrink, J., Fishman, J., and Nganga, D.: Ozone over southern Africa during SAFARI-92/TRACE A, Journal of Geophysical Research, 101 (D19), 23 793-23 807, 1996.

Thompson, A. M., Doddridge, B. G., Witte, J. C., Hudson, R. D., Luke, W. T., Johnson, J. E., Johnson, B. J., Oltmans, S. J., and Weller, R.: A tropical Atlantic paradox: shipboard and satellite views of a tropospheric ozone maximum and wave-one in January-February 1999, Geophysical Research Letters, 27, 3317-3320, 2000.

Thompson, A. M., Witte, J. C., Oltmans, S. J., Schmidlin, F. J., Logan, J. A., Fujiwara, M., Kirchhoff, V. W. J. H., Posny, F., Coetzee, G., Hoeger, B., Kawakami, S., and Ogawa, T.: The 19982000 SHADOZ (Southern Hemisphere Additional Ozonesondes) tropical ozone climatology. 2. Tropospheric variability and the zonal wave-one, Journal of Geophysical Research, 108 (D2), 8241, doi: 10.1029/2002JD002241, 2003.

Tyson, P. D., Garstang, M., Thompson, A. M., Diab, R. D., Browell, E. V., and D'Abreton, P. C.: Correspondence between ozone measurements, transport and production of ozone over south central Africa, Journal of Geophysical Research, 102 (D9), 10623 $10636,1997$.

Zachariasse, M., van Velthoven, P. F. J., Smit, H. G. J., Lelieveld, J., Mandal, T. K., and Kelder, H.: Influence of stratospheric tropospheric exchange on tropopsheric ozone over the tropical Indian Ocean during the winter monsoon, Journal of Geophysical Research, 105 (D12), 15 403-15 416, 2000. 